\title{
A NOTE ON THE S-CURVE DYNAMICS OF COMMODITY TRADE BETWEEN BRAZIL AND THE UNITED STATES
}

\author{
Mohsen Bahmani-OskooeE* \\ DAN $\mathrm{XI}^{* *}$
}

\begin{abstract}
The S-curve hypothesis postulates that the correlation coefficient between the current exchange rate and past trade balance values may be negative. However, the correlation between the current exchange rate and future values of the trade balance may be positive. Previous research using aggregate trade flows between Brazil and rest of the world find weak support for the curve. When we disaggregate Brazil's trade flows with the U.S. and investigate 95 industries that trade between the two countries, we find support for the S-curve in 51 industries. Small and large industries and durable and non-durable commodities are found to benefit from currency devaluation.
\end{abstract}

JEL classification: F31

Keywords: S-curve, industry data, Brazil, the United States

\section{INTRODUCTION}

A country that is experiencing a decline in its net exports may adhere to currency devaluation or allow its currency to depreciate, but due to adjustment lags such as recognition, production, delivery, etc. the trade balance may continue to deteriorate, with improvement coming later. This short-run pattern of movement of the trade balance subsequent to devaluation has been tested by two concepts that rely upon two different approaches. The J-curve introduced theoretically by Magee (1973) and tested empirically by Bahmani-Oskooee (1985) mostly relies upon a reduced-form trade balance model and different estimation techniques and regression analysis. The S-curve introduced by Backus et al. (1994) relies upon a cross-correlation function between past and future values of the trade balance and the current terms of trade or the real exchange rate. Bahmani-Oskooee and Hagerty (2010) provide a comprehensive review of both concepts, classifying all studies into three categories. The first group uses aggregate trade flows between

\footnotetext{
* The Center for Research on International Economics and Department of Economics, University of Wisconsin-Milwaukee, Milwaukee, WI 53201. Email: bahmani@uwm.edu.

** School of Finance, University of International Business and Economics, Beijing, China. Email: danxi83@ gmail.com.
} 
one country and the rest of the world. To reduce aggregation bias, the second group uses trade flows between two countries. To further reduce the aggregation bias, the third group uses trade flows between two countries disaggregated by commodity. The evidence in support of both the S-curve and the J-curve increases with the level of disaggregation.

In this paper we concentrate on the experience of Brazil. Can Brazil enjoy an improvement in its trade balance in the future as a result of currency depreciation? Four studies have tried to answer this question by relying upon the J-curve concept. The results are mixed at best. Bahmani-Oskooee and Malixi (1992), who test the J-curve phenomenon for several developing countries, include Brazil in their sample and find support for the J-curve in Brazil. So do Gomes and Paz (2005), who only consider the case of Brazil. However, Moura and Da Silva (2005), who also use Brazilian data, do not find any support for the J-curve. The three studies use aggregate trade data between Brazil and rest of the world, hence they may suffer from aggregation bias. To reduce the bias and search for further evidence in support of the J-curve, Bahmani-Oskooee et al. (2012) concentrate on trade between Brazil and its major trading partner, the United States, and consider the experiences of 92 industries. Using the bounds-testing approach to cointegration and error-correction modeling, which distinguishes the short-run effects of currency depreciation from its long-run effects, they are able to support the J-curve in almost one-third of the industries.

As for Brazil's experience with the S-curve, only two studies have estimated the curve for developing countries. While Senhadji (1998), who tests the curve for 36 developing countries using aggregate trade data, does not include Brazil in his analysis, Parikh and Shibata (2004), testing the curve for 64 developing countries, include Brazil and find weak support for the S-curve there. These studies use aggregate trade flows between each country and rest of the world, the same procedure as Backus et al. (1994), who test the curve for 11 OECD countries. In an effort to reduce aggregation bias, Bahmani-Oskooee and Ratha (2007a) disaggregate trade flows by trading partners and provide more support for the S-surve in trade between the U.S. and each of its major trading partners. Unfortunately, they do not include Brazil as a partner.

In this paper, we examine trade between the U.S. and Brazil exclusively and try to find stronger support for the S-curve using bilateral trade flows. To further bolster our results we disaggregate bilateral trade 
flows and estimate the curve for each of the 95 industries that trade between the two countries, finding support for the S-curve in 52 cases. To demonstrate how we arrive at our findings, in Section 2 we explain the method of generating the S-curve. The findings are reported in Section 3 and a summary is provided in Section 4.

\section{DAtA AND Methodology}

As indicated in the previous section, the S-curve is based on the crosscorrelation between the current real exchange rate and future as well as past values of the trade balance. Thus, following Bahmani-Oskooee and Ratha (2007b) and the literature, we define the cross-correlation coefficient (COR) between the trade balance $(T B)$ and the real exchange rate $(R E)$ as:

$$
C O R=\frac{\sum\left(R E_{t}-R \bar{E}\right)\left(T B_{t+k}-T \bar{B}\right)}{\sqrt{\sum\left(R E_{t}-R \bar{E}\right)^{2}\left(T B_{t+k}-T \bar{B}\right)^{2}}}
$$

where $R \bar{E}$ and $T \bar{B}$ are the mean of all observations over the study period. By allowing $k$ to take negative values such as $-5,-4,-3,-2$, and -1 , we calculate cross-correlation coefficients between the current exchange rate and past vales of the trade balance. And by allowing $k$ to take positive values such as $1,2,3,4$, and 5 , we calculate the same correlation between the current exchange rate and future values of the trade balance. The S-curve is then produced by plotting constructed correlation coefficients against corresponding lags and leads. ${ }^{1}$

Before we proceed, it should be mentioned that since the industry-level data are reported by the U.S., we define the $T B$ and $R E$ from the U.S. perspective. Thus, for each industry $i$, the trade balance is defined as $T B_{i}=\left(X_{i}-M_{i}\right) / G D P_{U S}$ where $X_{i}$ is U.S. exports of industry $i$ to Brazil, $M_{i}$ is U.S. imports of the same industry from Brazil, and GDPUS is U.S. gross domestic product. All variables are measured in nominal U.S. dollars so that the ratio measures the trade balance in terms of domestic output. This definition is followed by all previous research on the S-surve. The real exchange rate between the U.S. dollar 
and the Brazilian real is defined as $R E=P_{B R} /\left(P_{U S} \cdot E\right)$ where $P_{B R}$ is the price level in Brazil, PUS is the price level in the U.S., and $E$ is the nominal exchange rate defined as the number of Brazilian real per U.S. dollar. Thus, an increase in $R E$ reflects a real depreciation of the dollar, which implies that the contemporaneous correlation coefficient between the two variables is expected to be positive. ${ }^{2}$

\section{RESULTS}

We are now in a position to plot our constructed COR variable against a number of lags and leads to see if we can provide stronger support for the S-curve at the commodity level. We first summarize our findings in Table 1, which contains information such as industry code, name, their trade share, and an indication of whether the S-curve is supported.

\section{Table 1. Industries studied and their trade shares}

\begin{tabular}{llll}
\hline Code & \multicolumn{1}{c}{ Industry name } & Trade share & Support \\
\hline 13 & Meat in airtight containers n.e.s. & 0.001688 & \\
48 & Cereal preps. and preps. of flour & 0.000634 & Yes \\
51 & Fruit, fresh, and nuts excl. oil & 0.004393 & \\
53 & Fruit, preserved and fruit preparations & 0.0068 & \\
61 & Sugar and honey & 0.006284 & Yes \\
62 & Sugar confectionery, sugar preps. & 0.000662 & \\
81 & Feed stuff for animals & 0.000483 & \\
112 & Alcoholic beverages & 0.000168 & \\
122 & Tobacco manufactures & $4.13 \mathrm{E}-05$ & $1.46 \mathrm{E}-05$ \\
211 & Hides and skins, excluding fur skins & 0.005775 & Yes \\
231 & Crude rubber including synthetic and recycled & $8.17 \mathrm{E}-05$ & \\
273 & Stone, sand and gravel & 0.002225 & \\
276 & Other crude minerals & 0.00366 & \\
283 & Non-ferrous ores and concentrates & 0.000293 & \\
284 & Non-ferrous metal scrap & 0.001894 & \\
291 & Crude animal materials, n.e.s. & 0.000851 & \\
292 & Crude vegetable materials, n.e.s. & & \\
\hline
\end{tabular}

2. The data on price levels (measured by PPI for both countries), the exchange rate, and U.S. GDP are from the International Financial Statistics published by the International Monetary Fund. The industrylevel trade data are from World Bank's WITS system (which in turn receives the data from the United Nations' COMTRADE database). All data are annual over the 1971-2010 period. 


\section{Table 1. (continued)}

\begin{tabular}{|c|c|c|c|}
\hline Code & Industry name & Trade share & Support \\
\hline 422 & Other fixed vegetable oils & 0.000139 & \\
\hline 431 & Animal/vegetable oils and fats, processed & 0.000784 & \\
\hline 512 & Organic chemicals & 0.057495 & Yes \\
\hline 513 & Inorganic chemicals elements, oxides & 0.013377 & Yes \\
\hline 531 & Synthetic organic dyestuffs, natural & 0.002277 & \\
\hline 532 & Dyeing and tanning extracts & $9.46 \mathrm{E}-05$ & \\
\hline 541 & Medicinal \& pharmaceutical products & 0.02464 & Yes \\
\hline 571 & Explosives and pyrotechnic products & 0.000178 & Yes \\
\hline 581 & Plastic materials, regenerated & 0.032407 & Yes \\
\hline 599 & Chemical materials and products & 0.017733 & Yes \\
\hline 611 & Leather & 0.001583 & \\
\hline 612 & Manuf. of leather & $8.83 \mathrm{E}-05$ & Yes \\
\hline 629 & Articles of rubber, n.e.s. & 0.010798 & \\
\hline 631 & Veneers, plywood boards and other wood & 0.001198 & Yes \\
\hline 632 & Wood manufactures, n.e.s. & 0.003398 & Yes \\
\hline 641 & Paper and paperboard & 0.007375 & Yes \\
\hline 642 & Articles of paper, pulp, paperboard & 0.001065 & Yes \\
\hline 651 & Textile yarn and thread & 0.000954 & Yes \\
\hline 652 & Cotton fabrics, woven excluding narrow & 0.000308 & \\
\hline 653 & Text fabrics woven excluding narrow & 0.000555 & Yes \\
\hline 654 & Tulle, lace, embroidery, ribbons & $4.68 \mathrm{E}-05$ & Yes \\
\hline 655 & Special textile fabrics and related & 0.003323 & \\
\hline 656 & Made up articles, wholly or chiefly & 0.002021 & Yes \\
\hline 657 & Floor coverings, tapestries, etc. & 0.000257 & Yes \\
\hline 661 & Lime, cement and fabr. bldg.mat. & 0.010213 & Yes \\
\hline 662 & Clay and refractory construction materials & 0.001563 & Yes \\
\hline 663 & Mineral manufactures, n.e.s. & 0.00244 & \\
\hline 664 & Glass & 0.00133 & Yes \\
\hline 665 & Glassware & 0.000458 & Yes \\
\hline 666 & Pottery & $3.53 \mathrm{E}-05$ & Yes \\
\hline 667 & Pearls and precious and semi-precious stones & 0.000872 & \\
\hline 671 & Pig iron, spiegeleisen, sponge iron & 0.016903 & \\
\hline 672 & Ingots and other primary forms of iron & 0.007023 & \\
\hline 673 & Iron and steel bars, rods, angles, & 0.002921 & \\
\hline 677 & Iron and steel wire & 0.000471 & Yes \\
\hline 678 & Tubes, pipes and fittings of iron ore & 0.003005 & \\
\hline 682 & Copper & 0.001139 & \\
\hline 689 & Misc. non-ferrous base metals & 0.001535 & \\
\hline 692 & Metal containers for storage & 0.001821 & Yes \\
\hline 693 & Wire products ex electric and fence & 0.000451 & \\
\hline
\end{tabular}


Table 1. (continued)

\begin{tabular}{|c|c|c|c|}
\hline Code & Industry name & Trade share & Support \\
\hline 694 & Nails, screws, nuts, bolts, rivets & 0.001425 & Yes \\
\hline 695 & Tools for use in the hand or in machine & 0.002828 & \\
\hline 696 & Cutlery & 0.000824 & Yes \\
\hline 697 & Household equipment of base metals & 0.000612 & Yes \\
\hline 698 & Manufactures of metal, n.e.s. & 0.003871 & Yes \\
\hline 711 & Power generating machinery & 0.02137 & \\
\hline 712 & Agricultural machinery & 0.00546 & Yes \\
\hline 714 & Office machines & 0.016514 & Yes \\
\hline 715 & Metalworking machinery & 0.001971 & \\
\hline 717 & Textile and leather machinery & 0.000671 & Yes \\
\hline 718 & Machines for special industries & 0.032678 & Yes \\
\hline 719 & Machinery and appliances non electrical & 0.059249 & Yes \\
\hline 722 & Electric power machinery and switch & 0.01633 & Yes \\
\hline 723 & Equipment for distributing electricity & 0.002378 & Yes \\
\hline 724 & Telecommunications apparatus & 0.015917 & Yes \\
\hline 725 & Domestic electrical equipment & 0.000535 & Yes \\
\hline 729 & Other electrical machinery and appliances & 0.015454 & Yes \\
\hline 731 & Railway vehicles & 0.003438 & \\
\hline 732 & Road motor vehicles & 0.022861 & Yes \\
\hline 734 & Aircraft & 0.013807 & \\
\hline 812 & Sanitary, plumbing, heating \& light & 0.000504 & Yes \\
\hline 821 & Travel goods, handbags and similar & 0.00018 & Yes \\
\hline 841 & Clothing except fur clothing & 0.000653 & Yes \\
\hline 851 & Footwear & 0.006768 & \\
\hline 861 & Scientific, medical, optical, meas. & 0.021344 & Yes \\
\hline 862 & Photographic and cinematographic su & 0.002191 & \\
\hline 863 & Developed cinematographic film & $1.54 \mathrm{E}-06$ & \\
\hline 864 & Watches and clocks & 0.000206 & \\
\hline 891 & Musical instruments, sound recorder & 0.002976 & \\
\hline 892 & Printed matter & 0.002153 & \\
\hline 893 & Articles of artificial plastic mater. & 0.003287 & Yes \\
\hline 894 & Perambulators, toys, games and sporting & 0.001879 & Yes \\
\hline 895 & Office and stationery supplies, n.e.s. & 0.000638 & \\
\hline 896 & Works of art, collector pieces & 0.000601 & \\
\hline 897 & Jewelry and gold/silver watches & 0.001288 & Yes \\
\hline 899 & Manufactured articles, n.e.s. & 0.003152 & Yes \\
\hline 931 & Special transactions \& goods not classified & 0.100907 & Yes \\
\hline
\end{tabular}


From the last column of the table, we gather that the S-curve is supported in 52 out of 95 industries, which is a much stronger level of support than for the J-curve concept investigated by Bahmani-Oskooee et al. (2012), who find that the same data set supports the J-curve in only 31 cases. It appears that neither industry size nor industry classification (e.g., durable versus non-durable) play any role in the outcome. ${ }^{3}$ While many of the industries are small as measured by the size of their trade shares, the four largest industries are also among those that support the S-curve. These include industry code 718 with $3.26 \%, 719$ with $5.92 \%, 732$ with $2.28 \%$, and 931 with $10.09 \%$. For brevity, in Figure 1 we report only the plots of the curves for industries that support the S-pattern.

\section{Figure 1. S-curves in industries that support the pattern}

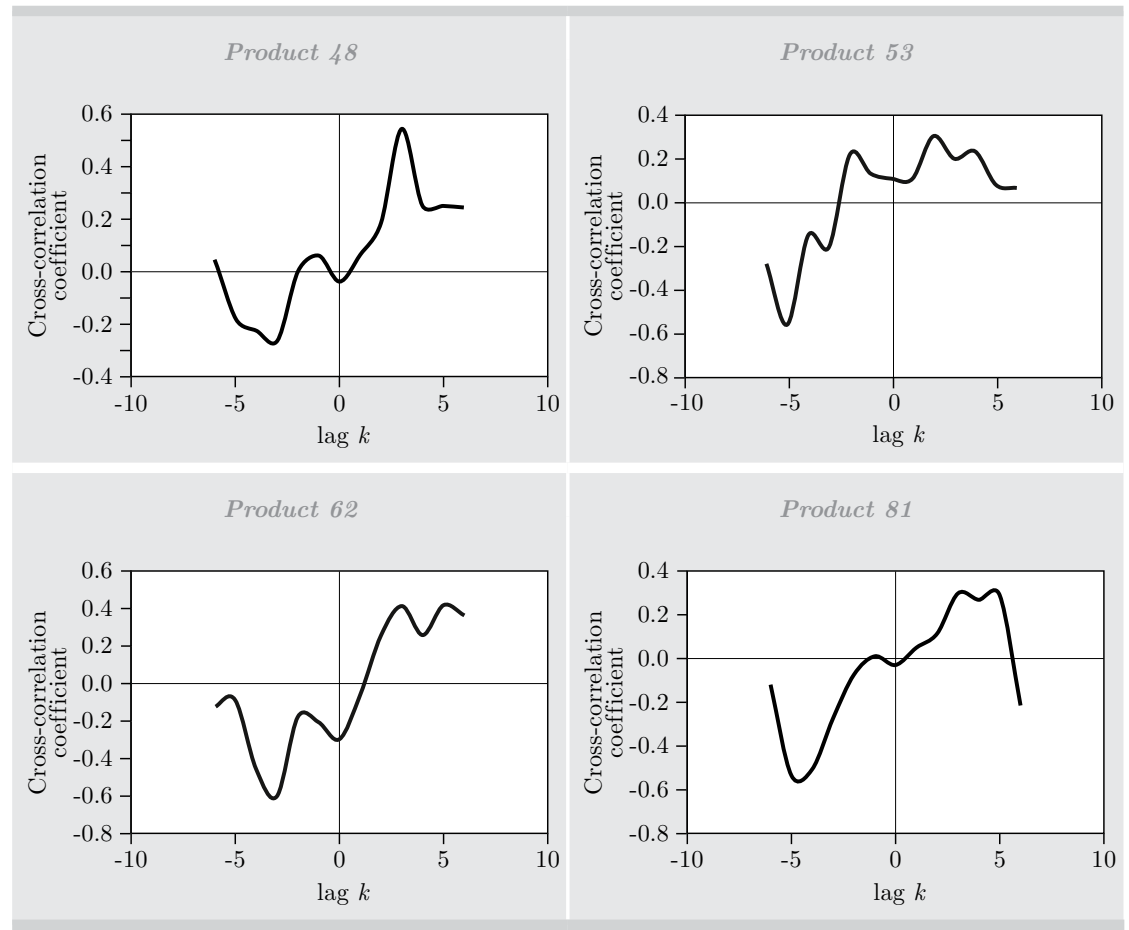

3. This finding is consistent with Bahmani-Oskooee and $\mathrm{Xu}$ (2013) who conduct a similar analysis for U.S.-Mexico industry-level data. It is also consistent with Bahmani-Oskooee and Ratha (2010) who do the same for U.S.-China trade. 
Figure 1. (continued)
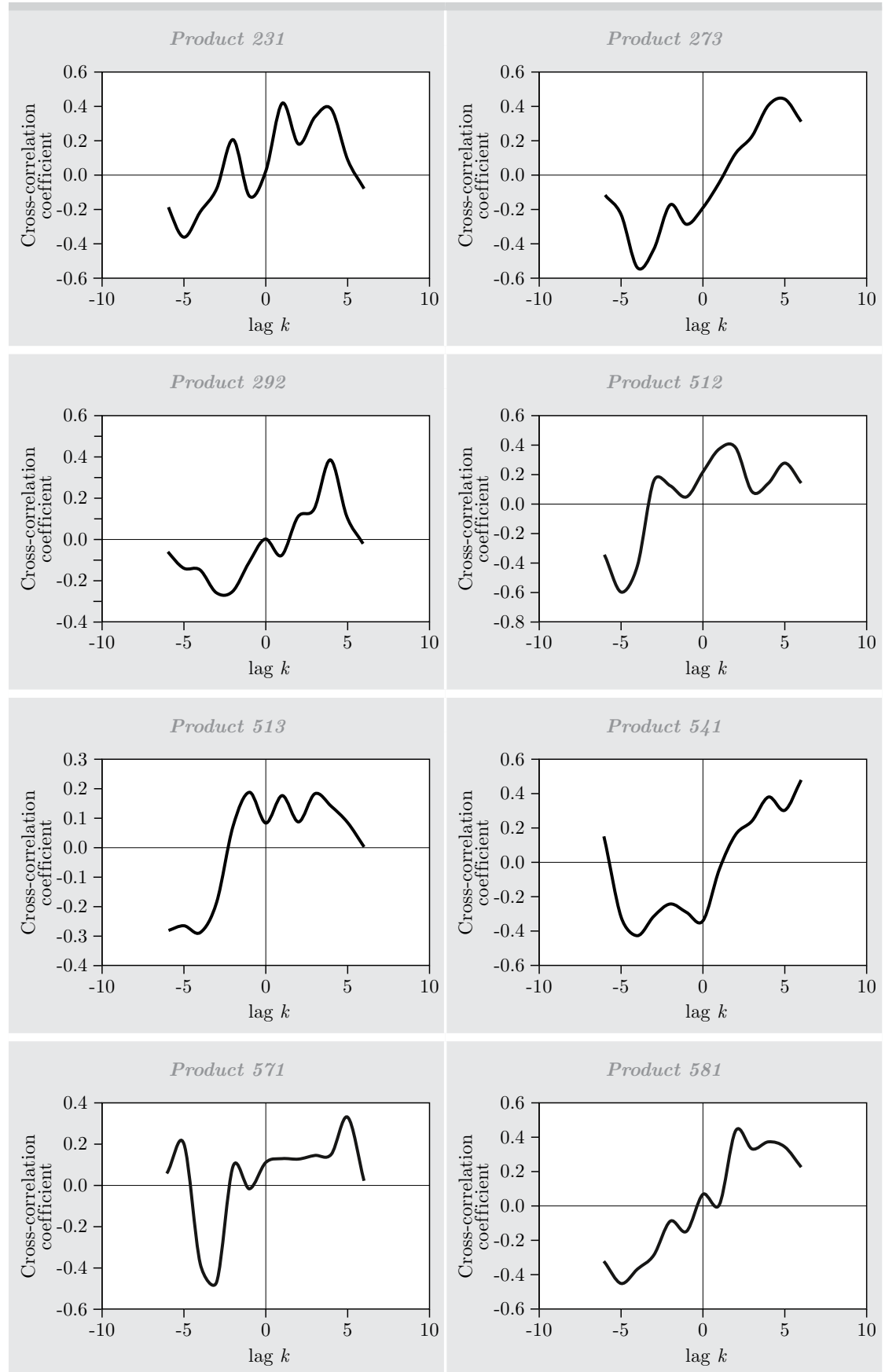
Figure 1. (continued)
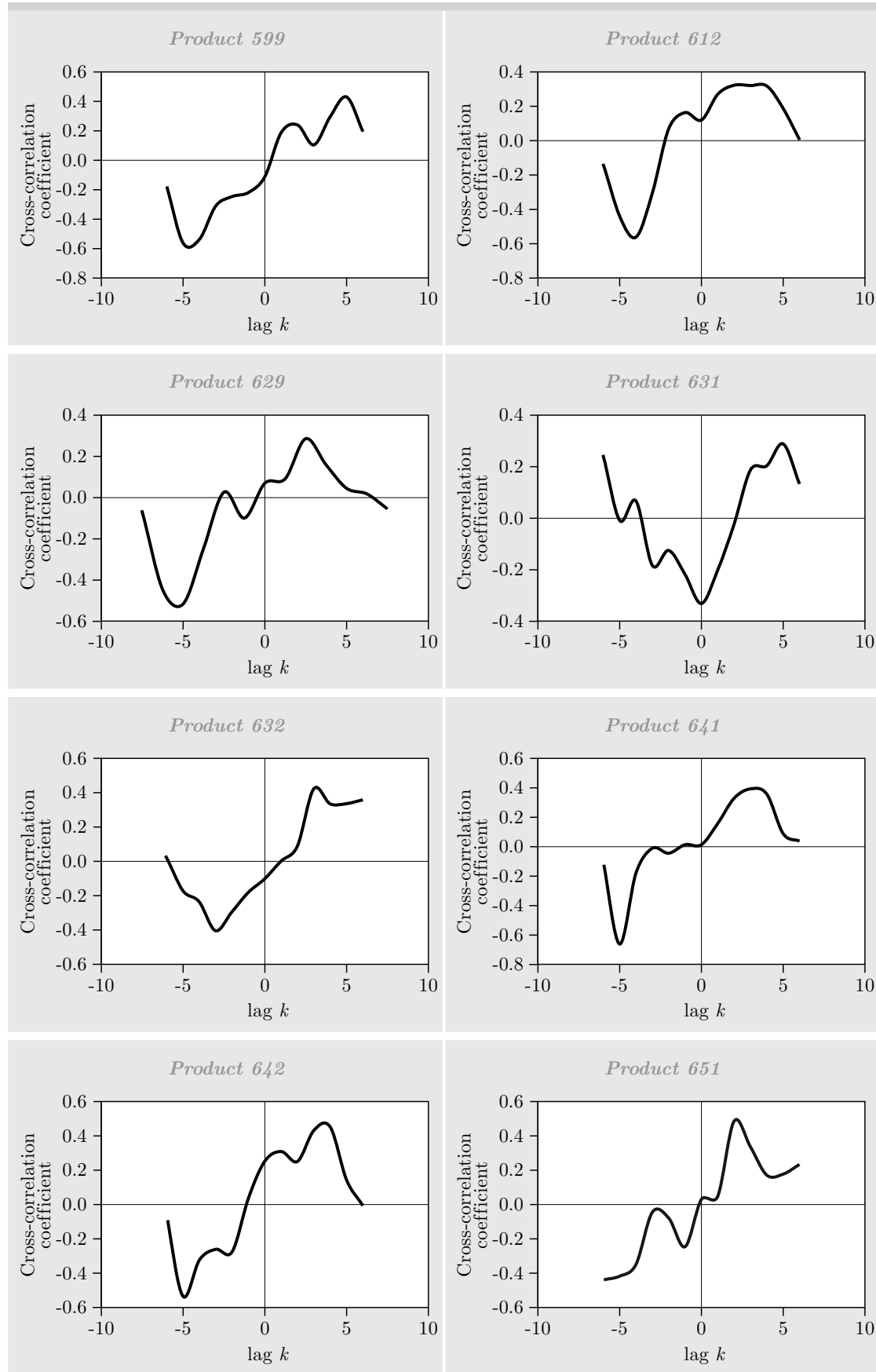
Figure 1. (continued)
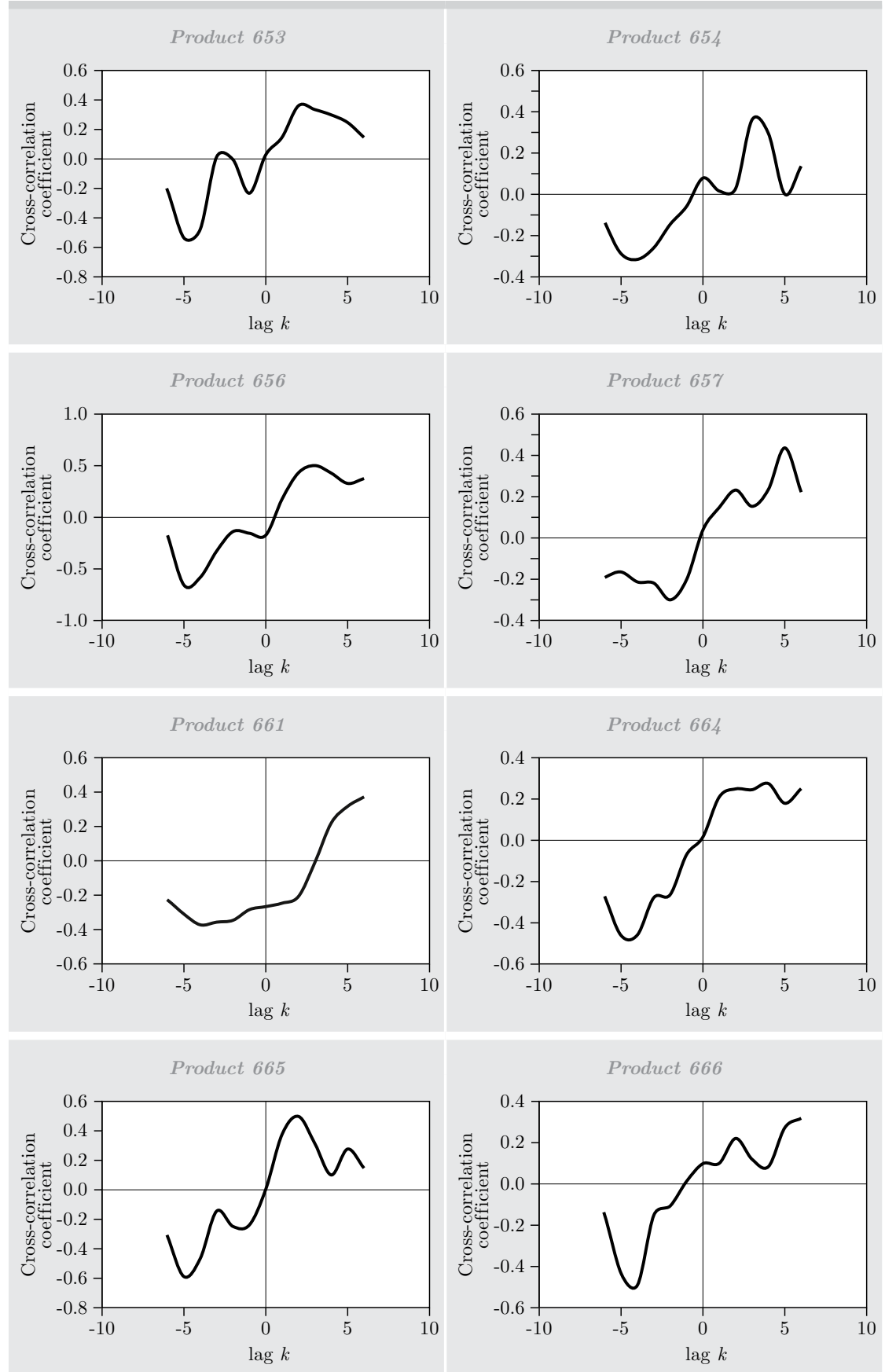
Figure 1. (continued)
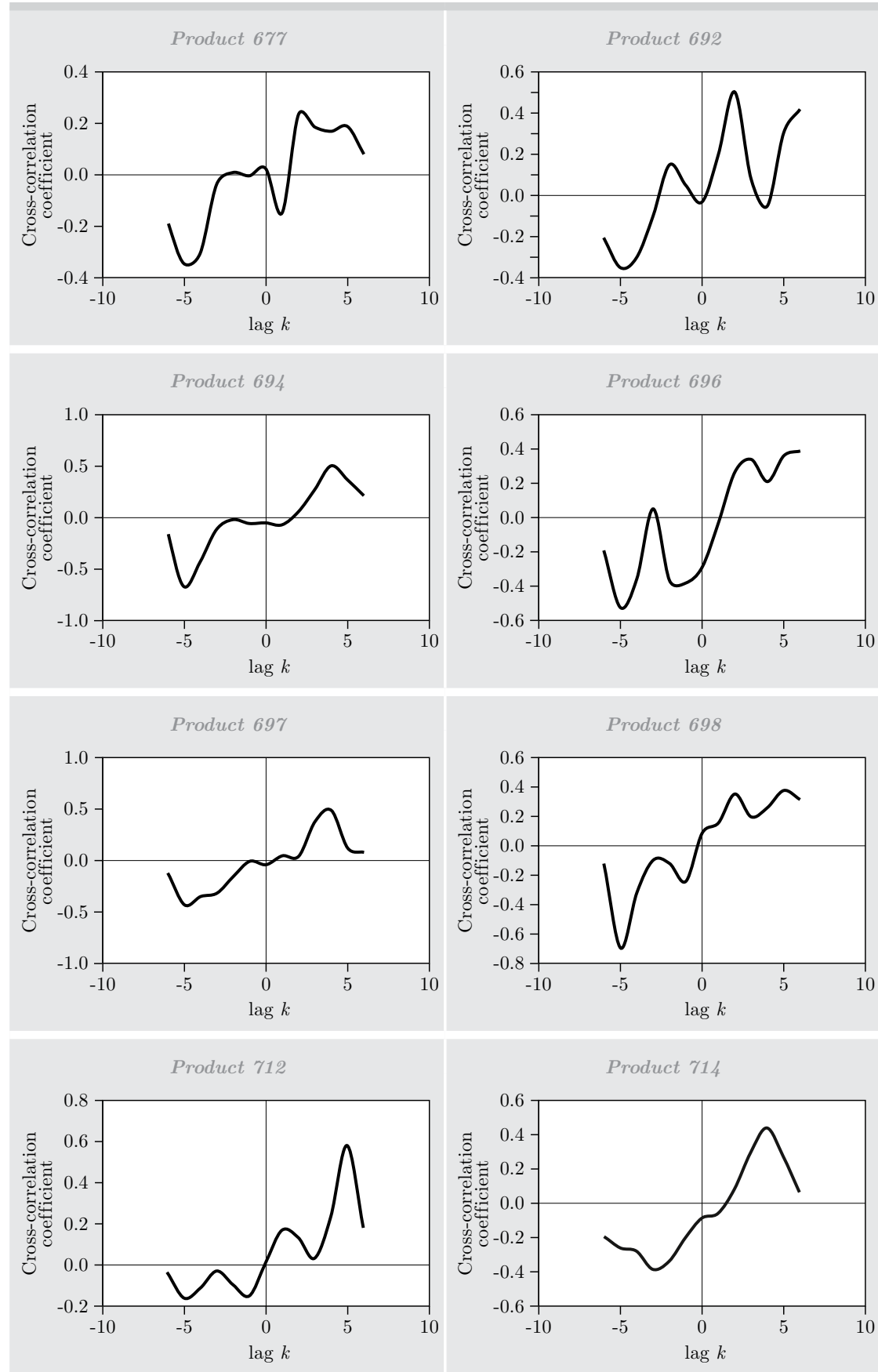
Figure 1. (continued)
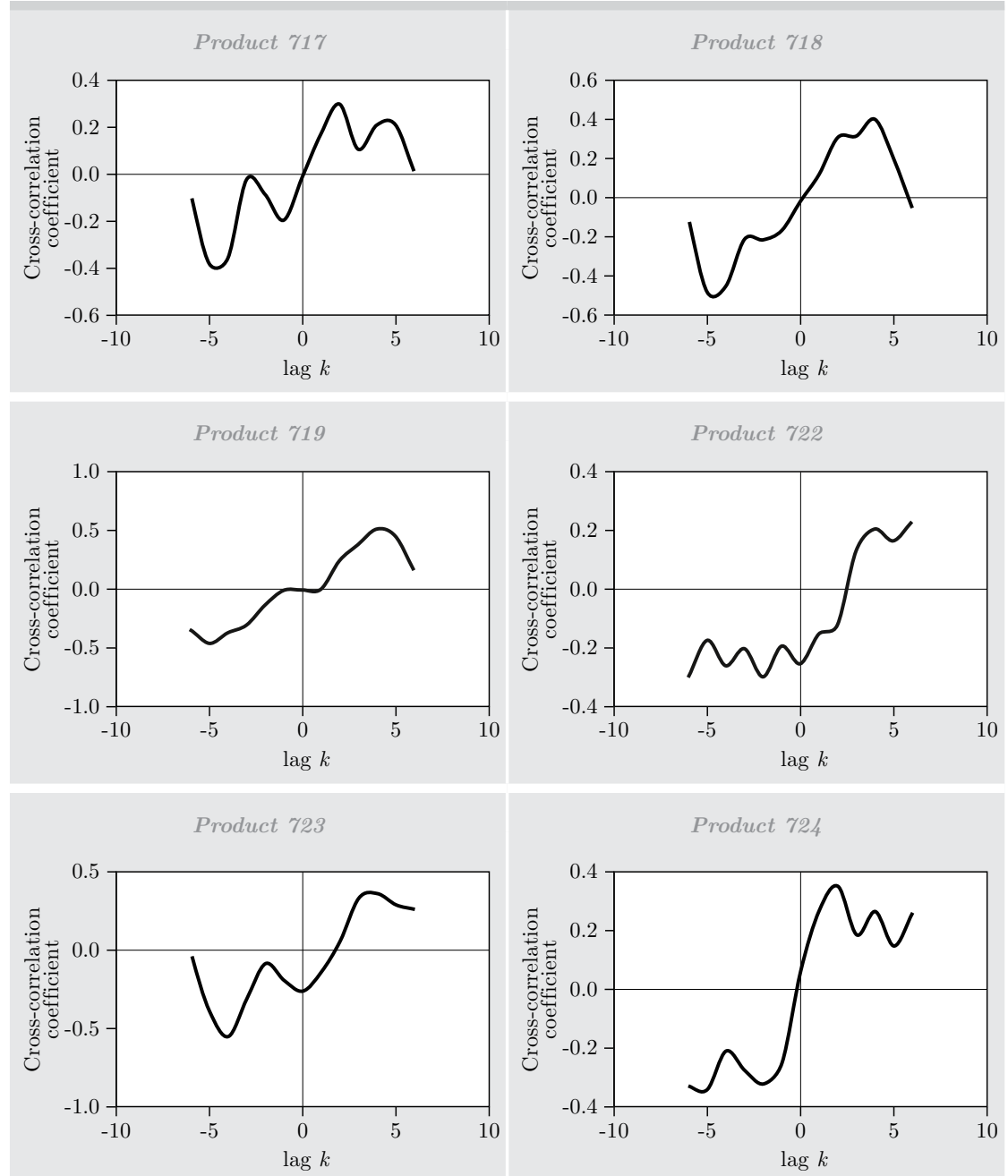

Product 724
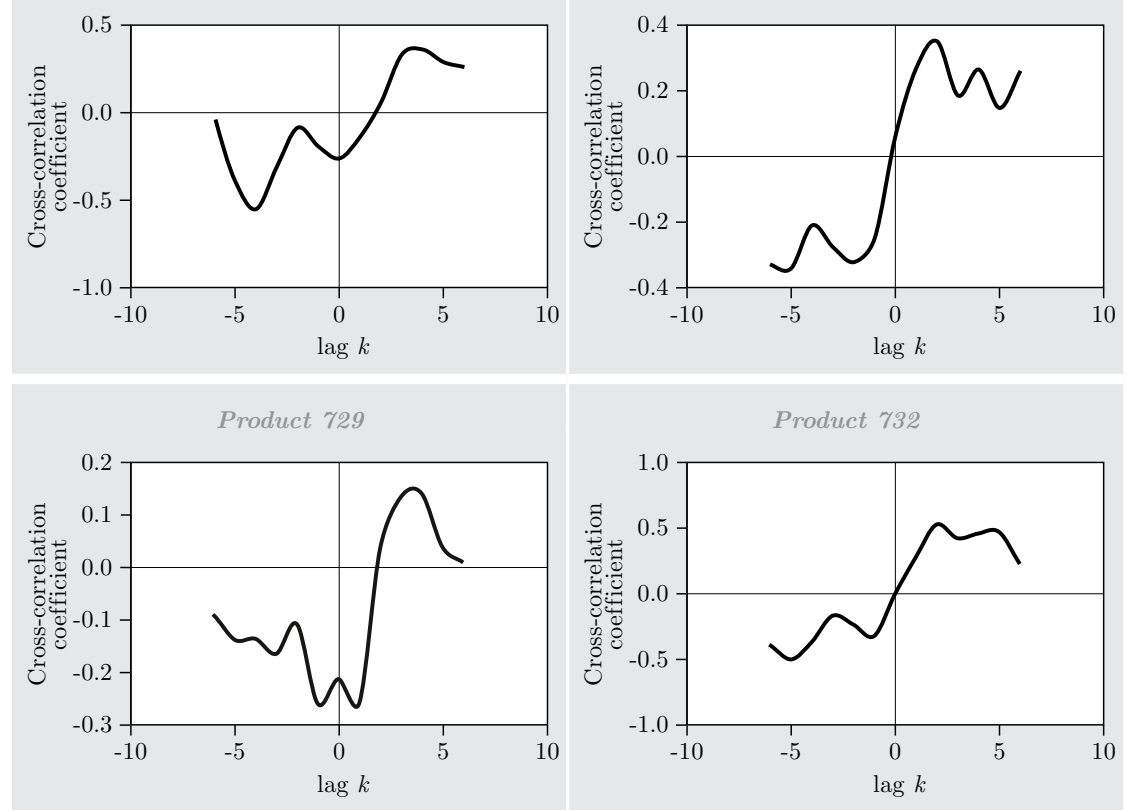
Figure 1. (continued)
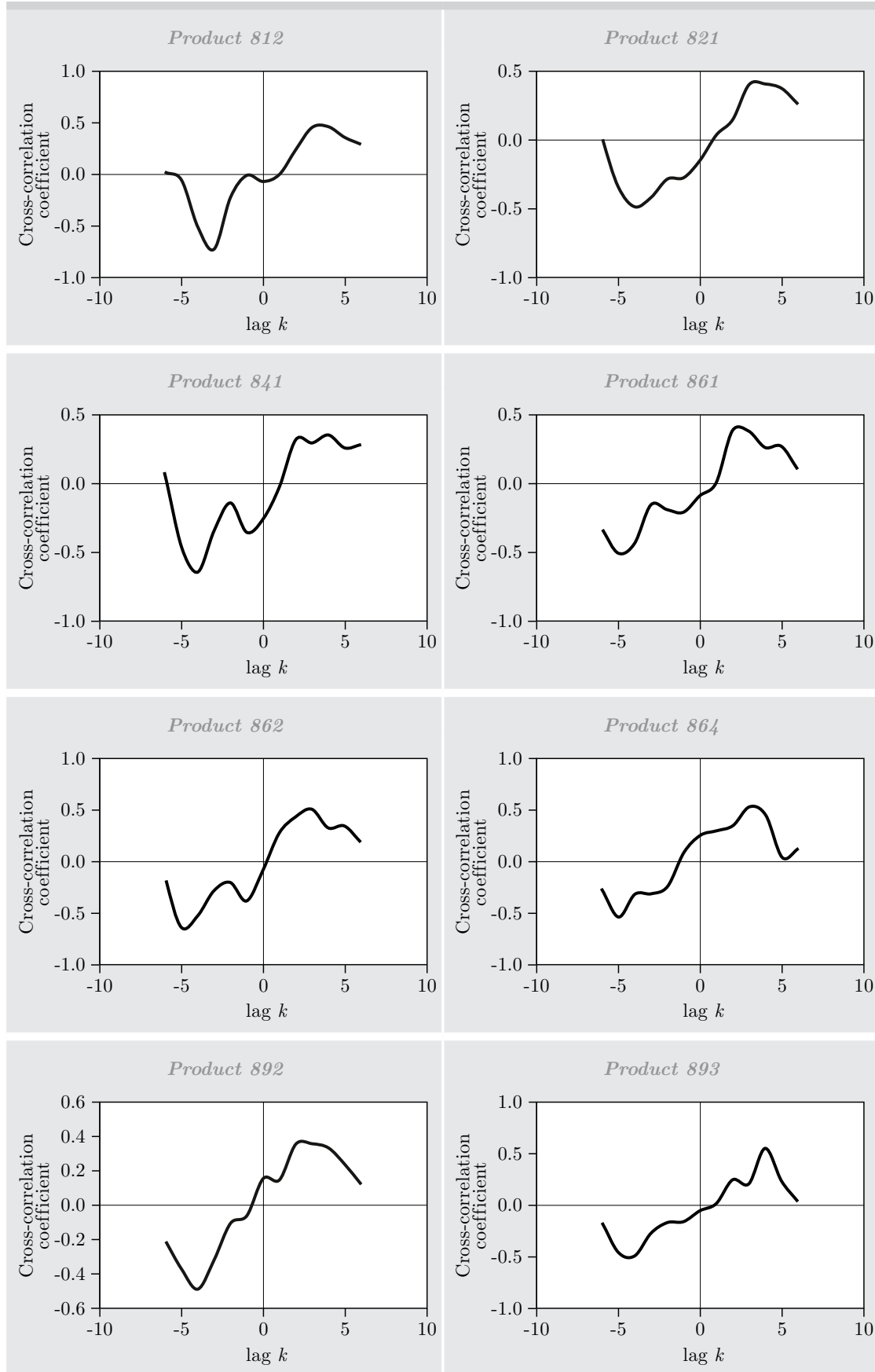
Figure 1. (continued)

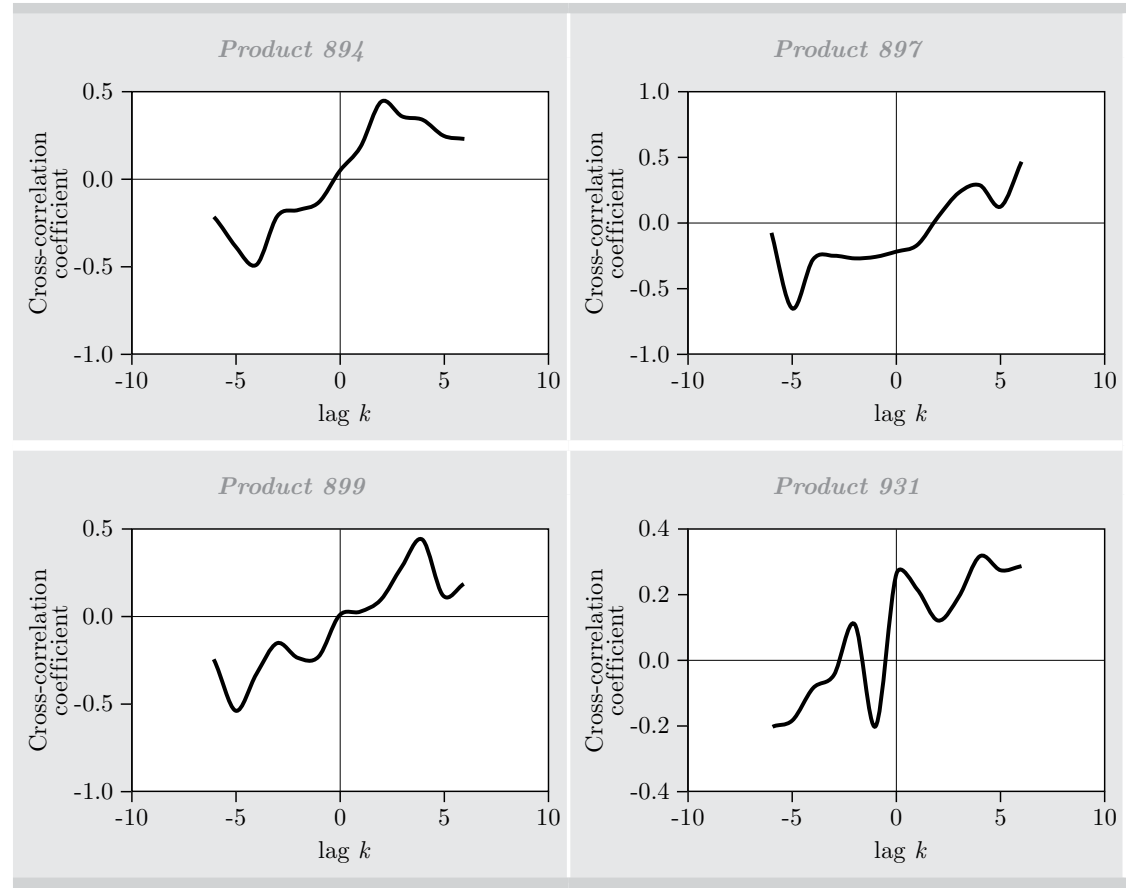

Source: Authors' construction.

\section{SUMMARY}

A country that is experiencing a decline in net exports or deterioration in its trade balance may adhere to currency devaluation or allow its currency to depreciate. Due to lags such as recognition, production, replacement, delivery, etc. the impact of devaluation is not instantaneous. The trade balance continues to deteriorate after devaluation and improvement comes only after the adjustment lags are realized. This short-run deterioration followed by an improvement can be tested using either the J-curve or the S-curve concept.

These curves are tested empirically by using the aggregate trade flows of one country with the rest of the world or between two countries using bilateral trade flows. In this paper we consider the experience of Brazil with the S-curve phenomenon. A previous study that includes Brazil among many other developing countries and tests the S-curve using aggregate trade flows between Brazil with the rest of the world finds weak support for the S-curve. However, in our study, we consider 
not only the trade flows between Brazil and one of its major trading partners, the U.S., but we take an additional step to disaggregate the trade flows between the two countries by industry and investigate the experience of each of the 95 industries involved in that trade between the two countries. At this disaggregated level, we find support for the S-curve in 52 cases, a result that had been masked by aggregate data. Further analysis reveals that the S-pattern emerges for small as well as large industries and in durable as well as non-durable commodities, identifying industries that will reap the benefits of currency devaluation. 


\section{REFERENCES}

Backus, D.K., P.J. Kehoe, and F.E. Kydland (1994). "Dynamics of the trade balance and the terms of trade: The J-curve?" American Economic Review 84(1): 84-103.

Bahmani-Oskooee, M. (1985). "Devaluation and the J-curve: Some evidence from LDCs," Review of Economics and Statistics 67(3): 500-04.

Bahmani-Oskooee, M. and M. Malixi (1992). "More evidence on the J-curve from LDCs," Journal of Policy Modeling 14(5): 641-53.

Bahmani-Oskooee, M. and A. Ratha (2007a). "The S-curve dynamics of U.S. bilateral trade," Review of International Economics 15(2): 430-39.

Bahmani-Oskooee, M. and A. Ratha (2007b). "Bilateral S-curve between Japan and her trading partners," Japan and the World Economy, 19(4): 483-9.

Bahmani-Oskooee, M. and S.W. Hegerty (2010). "The J- and S-curves: A survey of the recent literature," Journal of Economic Studies 37(6): 580-96.

Bahmani-Oskooee, M. and A. Ratha (2010). "S-curve dynamics of trade between U.S. and China," China Economic Review 21(2): 212-23.

Bahmani-Oskooee, M. and J. Xu (2013). "The S-curve dynamics of U.S.-Mexico commodity Trade," Journal of Applied Economics 16(1): 33-48.

Bahmani-Oskooee, M., H. Harvey, and S.W. Hegerty (2012). "Brazil-U.S. commodity trade and the J-curve," Working paper, University of Wisconsin-Milwaukee.

Gomes, F. and L. Paz (2005). "Can real exchange rate devaluation improve the trade alance? The 1990-1998 Brazilian case," Applied Economics Letters 12(9): 525-8.

Magee, S. P. (1973). "Currency contracts, pass through and devaluation," Brooking Papers on Economic Activity I: 303-25.

Moura, G. and S. Da Silva, (2005). "Is there a Brazilian J-curve?" Economics Bulletin 6(10): 1-17.

Parikh, A. and M. Shibata (2004). "Dynamics of the relationship between the terms of trade and the trade balance in developing countries of Asia, Africa, and Latin America," Journal of Quantitative Economics 2: 104-21.

Senhadji, A. S. (1998). "Dynamics of the trade balance and the terms of trade in LDCs: The S-curve," Journal of International Economics 46(1): 105-31. 